\title{
Jurnal Manajemen dan Bisnis
}

Vol. 8, No. 2, Desember 2019, pp. 302-311

Sekolah Tinggi Ilmu Ekonomi Indragiri (STIE-I) Rengat

http://journal.stieindragiri.ac.id/index.php/jmbi

PENGARUH KOMPENSASI DAN DISIPLIN KERJA TERHADAP KINERJA

PERANGKAT DESA UNTUK MENSUKSESKAN PENYALURAN DANA DESA

DI DESA SUNGAI GUNTUNG TENGAH KECAMATAN RENGAT KABUPATEN INDRAGIRI HULU

\author{
Yenny Iskandar ${ }^{1)}$ Sry Windartini $^{2)}$ Suharmiyati $^{3)}$ \\ 1) 2) 3) Program Studi Manajemen, Sekolah Tinggi Ilmu Ekonomi Indragiri (STIE-I) Rengat \\ Jl. R. Soeprapto No. 14. Rengat | Telp. (0769) 21019| Kode Pos : 29312 | Inhu, Riau \\ 1)yennyiskandar@stieindragiri.ac.id ${ }^{2)}$ ikke@ @ stieindragiri.ac.id. ${ }^{3)}$ suharmiyati@ stieindragiri.ac.id \\ Submited: 2019.10.17 Reviewed: 2019.10.28 Accepted: 2019.11.13 \\ https://doi.org/10.34006/jmbi.v8i2.114
}

\begin{abstract}
This research was conducted at office Desa Sei Guntung Tengah, Kecamatan Rengat Kabupaten Indragiri Hulu. The aim is to determine the effect of Compensation on the performance of village officials in the success of Village Fund Distribution in desa Sungai Guntung Tengah, Kec. Rengat, Kabupaten Indragiri Hulu. The results of the study obtained by linear regression equation is that SPSS knows that constant (a) is 1.361. the coefficient of $X(b 1)$ is 0.385 and the coefficient of $X(b 2)$ is 0.355 . The correlation coefficient is known that $(X)$ compensation has a relationship with $(Y)$ the performance of village officials. This can be seen from the value of the multiple correlation coefficient $R$ is 0.813 meaning that it has a very strong and direct relationship. and then tested with a multiple coefficient of determination $(R 2)$ is 0.661 . this shows $(X)$ compensation can contribute to the variable $(Y)$ the performance of the village apparatus by $66.1 \%$. And the remaining $33.9 \%$ is influenced by other variables not examined in this study. $t$ count for compensation variable is 2.239 , in table $t$ with db 35 and significant level 0.025 is obtained 2.034. because t count $(2,239)>$ from t table $(2,034)$ then Ho is rejected and $\mathrm{Ha}$ is accepted, which means compensation has a significant influence on the performance of the village apparatus.
\end{abstract}

Keywords: Compensation, Dicipline, Performance of Village Officials

Abstrak

Penelitian ini dilakukan pada Kantor Desa Sungai Guntung Tengah Kecamatan Rengat Kabupaten Indragiri Hulu. Tujuan adalah untuk mengetahui pengaruh Kompensasi dan disiplin kerja terhadap Kinerja perangkat desa dalam mensukseskan Penyaluran Dana Desa di Desa Sungai Guntung Tengah Kecamatan Rengat Kabupaten Indragiri Hulu. Berdasarkan hasil pengujian persamaan regresi linear berganda dengan menggunakan program SPSS didapatlah nilai konstanta (a) adalah 1,361. koefisien X (b1) adalah 0,385 dan koefisien X (b2) adalah 0,355. Nilai koefisien korelasi diketahui bahwa (X) kompensasi mempunyai pengaruh dengan $(Y)$ kinerja aparat desa. Nilai koefisien korelasi berganda $R$ adalah 0,813 artinya memiliki hubungan yang sangat kuat serta searah. dan selanjutnya diuji dengan Koefisien determinasi berganda (R2) adalah 0,661. hal ini menunjukkan $(X)$ kompensasi dapat memberikan sumbangan terhadap variabel $(Y)$ kinerja perangkat desa sebesar 66,1\%. Dan sisanya 33,9\% di pengaruhi oleh variabel lain yang tidak diteliti dalam penelitian ini. F hitung (31,234) > F tabel (3,29) maka Ho ditolak dan Ha diterima. Artinya variabel kompensasi dan disiplin secara bersama - sama memiliki pengaruh signifikan terhadap kinerja perangkat desa pada Kantor Desa Sei Guntung Tengah Kecamatan Rengat Kabupaten Indragiri Hulu. Dan untuk uji t didapatlah t hitung untuk variabel kompensasi adalah 2,239, pada tabel t dengan db 35 dan taraf signifikan 0,025 di peroleh 2,034. karena t hitung (2,239) > dari pada t tabel (2,034) maka Ho ditolak dan Ha diterima, yang berarti kompensasi memiliki pengaruh yang signifikan terhadap kinerja perangkat desa. untuk variabel disiplin kerja adalah 2,586, pada tabel t dengan db 33 dan taraf signifikan 0,05 di peroleh 2,034. karena thitung $(2,586)>$ dari pada t tabel $(2,034)$ maka Ho ditolak dan Ha diterima, yang berarti disiplin memiliki pengaruh yang signifikan terhadap kinerja perangkat desa.

Kata Kunci: Kompensasi, Disiplin Kerja, Kinerja Perangkat Desa 


\section{PENDAHULUAN}

Desa adalah satu kesatuan masyarakat yang memiliki wilayah dan memiliki kewenangan untuk mengurus dan mengatur wilayahnya sesuai dengan aturan pemerintahan dan adat istiadat dengan dasar gotong royong yang memiliki norma dan tata cara dalam mengatur wilayahnya sendiri. Menurunnya semangat dan kegiatan kerja pegawai tentunya akan berdampak negatif terhadap kemajuan organisasi, misalnya pegawai terlambat masuk kerja, tidak menyelesaikan pekerjaan sesuai dengan target yang telah diciptakan, atau bahkan meliburkan diri pada waktu hari kerja.

Untuk mencapai kinerja perangkat desa yang baik di tuntutlah kebijakan kepala desa dan masyarakatnya, Kepala Desa Sungai Guntung Tengah harus menjalankan fungsinya sebagai kepala desa atau wilayah untuk bisa memberikan motivasi kepada aparatur desa atau staf desa seperti memberikan kompensasi, sehingga pekerjaan atau pelayanan yang akan di berikan kepada masyarakat juga lebih baik dan meningkat. Dan masyarakat pun akan merasakan pelayanan yang diberikan oleh pihak aparatur desa di Desa Sungai Guntung Tengah ini. Masyarakat untuk saat ini sudah bisa langsung memberikan penilaian terhadap kinerja aparatur desa, sebagai aparatur desa hendaknya bisa lebih fokus melayani masyarakat dan disini berikanlah pelayanan yang terbaik demi terwujudnya kehidupan desa yang sejahtera.

Untuk meningkatkan kinerja yang baik dari aparatur desa hendaknya pimpinan atau kepala desa memperhatikan pemberian kompensasi karena kompensasi ini merupakan tolak ukur atau faktor-faktor yang mempengaruhi kinerja. Kompensasi itu adalah balas jasa yang diterima oleh karyawan sebagai penerima kerja. Hal ini merupakan dorongan yang akan membawa karyawan atau staf desa untuk lebih giat lagi di dalam menjalankan tugasnya yaitu memberikan pelayanan kepada masyarakat.

\section{TELAAH PUSTAKA}

Kinerja dalam sebuah organisasi merupakan salah satu unsur yang tidak dapat dipisahkan dalam suatu lembaga organisasi, baik itu lembaga pemerintahan maupun lembaga swasta. Kinerja berasal dari kata Job Performance atau Actual Performance yang merupakan prestasi kerja atau prestasi sesungguhnya yang dicapai seseorang. (Astarina, 2018) Kinerja merupakan hasil kerja yang dilakukan oleh seseorang dalam melakukan tugasnya baik sebagai seorang pimpinan atau sebagai staf (Rivai, 2009 : 56) Kinerja organisasi (organizational performance) adalah ukuran seberapa efisien dan efektif organisasi dapat mencapai sasaran yang telah ditetapkan. (Wijayanto, 2012 : 7). Pengertian kinerja adalah gambaran mengenai tingkat pencapaian sasaran ataupun tujuan instansi pemerintah sebagai penjabaran dari visi, misi dan strategi instansi pemerintah yang mengindikasikan tingkat keberhasilan dan kegagalan pelaksanaan kegiatan-kegiatan sesuai dengan program dan kebijaksanaan yang ditetapkan. (Rulyanti et.al, 2017, 325-326). Dari beberapa temuan yang berkaitan dengan kinerja, maka hal-hal lain yang perlu diperhatikan adalah perlu adanya penambahan dalam latihan melalui studi kasus dan pemecahan masalah (Putri, 2018)

Terdapat beberapa faktor yang menjadi indikator maupun kriteria penilaian kinerja karyawan, yaitu :

1. Kualitas kerja

2. Kuantitas kerja

3. Keandalan

4. Sikap

Kompensasi adalah segala sesuatu yang diterima para karyawan sebagai balas jasa untuk kerja mereka (Handoko, 2011: 155). Kompensasi sebagai imbalan jasa yang diberikan kepada tenaga kerja, karena tenaga tersebut telah memberikan sumbangan tenaga dan pikiran demi kemajuan organisasi guna mencapai tujuan yang telah ditetapkan 
(Sastrohadiwiryo, 2006:181). Kompensasi dan disiplin kerja merupakan hal yang perlu diperhatikan dalam kegiatan organisasi, karena kedua hal tersebut dapat mempengaruhi kinerja karyawan, dalam melakukan tanggung jawab mereka di dalam organisasi. (Gunawan at al, 2016:1) Kompensasi sebagai semua pendapatan yang berbentuk uang, barang langsung atau tidak langsung yang diterima pegawai sebagai imbalan atas jasa yang diberikan kepada organisasi. Kompensasi merupakan istilah luas yang berkaitan dengan imbalan-imbalan finansial (financial reward) yang diterima oleh orang-orang melalui hubungan kepegawaian mereka dengan sebuah organisasi (Hasibuan, 2011:117). Kompensasi adalah fungsi Human Resource Management (HRM) yang berhubungan dengan setiap jenis reward (penghargaan) yang diterima individu sebagai balasan atas pelaksanaan tugas-tugas organisasi. Pegawai menukarkan tenaganya untuk mendapatkan reward financial maupun nonfinansial. (Kadarisman : $2012: 6$ ).

Adapun tujuan pemberian kompensasi antara lain adalah sebagai berikut: (Hasibuan, 2011: 121).

1) Ikatan kerja sama.

2) Kepuasan kerja.

3) Motivasi

4) Stabilitas karyawan

5) Disiplin.

6) Pengaruh serikat buruh.

7) Pengaruh pemerintah.

Insentif merupakan salah satu jenis penghargaan yang dikaitkan dengan prestasi kerja.Semakin tinggi prestasi kerja semakin besar pula insentif yang diterima. Sudah menjadi kebiasaan bahwa setiap perusahaan harus menetapkan target yang tinggi dan bila berhasil maka akan diberikan tambahan pendapatan (Hariandja, 2007 : 65).

(Iskandar, 2018) Kedisiplinan adalah adanya kesadaran dan kesediaan seorang pegawai untuk mentaati segala peraturan dan norma-norma yang ada di dalam suatu organisasi pemerintah. Bagi aparatur pemerintahan, disiplin tersebut mencakup unsur-unsur ketaatan, kesetiaan, kesungguhan dalam menjalankan tugas dan kesanggupan berkorban, dalam arti mengorbankan kepentingan pribadi dan golongannya untuk kepentingan Negara dan masyarakat. (Hasibuan, 2011:193). Kedisiplinan adalah kesadaran dan kesediaan seseorang menaati semua peraturan organisasi dan norma-norma social yang berlaku. Kesadaran disini merupakan sikap seseorang yang secara sukarela menaati semua peraturan dan sadar akan tugas dan tanggung jawabnya. (Hasibuan, 2011:193-194).

Sedangkan tujuan khusus pembinaan disiplin tenaga kerja antara lain : (Siswanto, 2005:292)

1. Agar tenaga kerja menepati segala peraturan dan kebijakan ketenagakerjaan maupun peraturan dan kebijalan organisasi yang berlaku, baik tertulis maupun tidak tertulis, serta melaksanakan perintah manajemen.

2. Dapat melaksanakan pekerjaan dngan sebaik-baiknya serta mampu memberikan pelayanan yang maksimal kepada pihak tertentu yang berkepentingan dengan organisasi sesuai dengan bidang pekerjaan yang di berikan kepadanya.

3. Dapat menggunakan dan memelihara sarana dan prasarana, barang dan jasa organisasi dengan sebaik-baiknya.

4. Dapat bertindak dan berperilaku sesuai dengan norma-norma yang berlaku pada organisasi.

5. Tenaga kerja mampu menghasilkan produktivitas yang tinggi yang sesuai dengan harapan organisasi baik dalam jangka pendek maupun jangka panjang. 


\section{METODE PENELITIAN}

Metode penelitian yang digunakan dalam adalah metode kuantitatif, yaitu metode yang menggambarkan tentang Kompensasi dan disiplin kerja terhadap kinerja perangkat desa yang akan di analisis dengan mengukur Kompensasi dan disiplin kerja terhadap kinerja perangkat desa. Jenis data untuk penelitian ini yang di gunakan adalah data primer dan data skunder.

\section{HASIL PENELITIAN DAN PEMBAHASAN}

\section{Analisis Pengaruh Kompensasi dan Disiplin Kerja terhadap Kinerja Perangkat Desa}

Untuk mengetahui hubungan dan pengaruh Kompensasi dan disiplin kerja terhadap kinerja Perangkat desa berikut ini akan di sajikan data dari hasil penelitian yang penulis lakukan.

Tabel 1 : Data Hasil Penelitian pada Kantor Desa Sei Guntung Tengah

\begin{tabular}{|c|c|c|c|}
\hline No. & Kompensasi $\left(\mathrm{X}_{1}\right)$ & Disiplin Kerja $\left(\mathrm{X}_{2}\right)$ & Kinerja Perangkat Desa(Y) \\
\hline 1 & 4.33 & 5.00 & 5.00 \\
\hline 2 & 4.33 & 5.00 & 5.00 \\
\hline 3 & 4.33 & 5.00 & 5.00 \\
\hline 4 & 4.00 & 4.67 & 4.67 \\
\hline 5 & 4.33 & 4.33 & 4.33 \\
\hline 6 & 4.33 & 4.67 & 4.67 \\
\hline 7 & 4.33 & 4.33 & 4.33 \\
\hline 8 & 4.00 & 4.33 & 4.67 \\
\hline 9 & 4.33 & 4.33 & 4.67 \\
\hline 10 & 4.00 & 4.33 & 4.67 \\
\hline 11 & 4.00 & 4.33 & 5.00 \\
\hline 12 & 3.67 & 4.33 & 4.33 \\
\hline 13 & 4.00 & 4.33 & 4.33 \\
\hline 14 & 4.00 & 3.67 & 4.00 \\
\hline 15 & 4.00 & 4.00 & 4.33 \\
\hline 16 & 4.33 & 4.67 & 4.00 \\
\hline 17 & 4.33 & 4.00 & 4.67 \\
\hline 18 & 3.67 & 4.00 & 4.00 \\
\hline 19 & 3.33 & 4.00 & 4.33 \\
\hline 20 & 3.67 & 3.67 & 4.33 \\
\hline 21 & 4.00 & 4.00 & 4.00 \\
\hline 22 & 3.67 & 3.67 & 4.33 \\
\hline 23 & 3.67 & 4.00 & 4.00 \\
\hline 24 & 3.33 & 4.00 & 4.00 \\
\hline 25 & 4.00 & 4.00 & 4.00 \\
\hline 26 & 3.67 & 3.67 & 4.33 \\
\hline 27 & 3.33 & 3.67 & 4.00 \\
\hline 28 & 3.00 & 3.67 & 3.67 \\
\hline 29 & 3.33 & 3.33 & 4.00 \\
\hline 30 & 3.33 & 4.00 & 3.67 \\
\hline 31 & 3.33 & 3.33 & 4.00 \\
\hline 32 & 3.00 & 3.33 & 3.67 \\
\hline 33 & 3.00 & 3.33 & 3.67 \\
\hline 34 & 3.00 & 3.33 & 3.67 \\
\hline 35 & 3.00 & 3.33 & 3.67 \\
\hline
\end{tabular}

Sumber : Data Olahan 
Dari tabel 1 diatas dapat kita lihat hasil kuisioner yang telah di sebarkan ke responden dari hasil tersebut kita bagi rata- rata sesuai dengan bobot masing- masing pernyataan dan di dapat disimpulkan bahwa tanggapan responden mengenai kompensasi dan disiplin kerja terhadap kinerja dikategorikan setuju.

\section{Analisis Regresi (Deskritif Statistik)}

Tabel 2 : Uji Regresi Linear berganda

Coefficients $^{\mathrm{a}}$

\begin{tabular}{|c|c|c|c|c|c|c|}
\hline \multirow{2}{*}{\multicolumn{2}{|c|}{ Model }} & \multicolumn{2}{|c|}{$\begin{array}{c}\text { Unstandardized } \\
\text { Coefficients }\end{array}$} & \multirow{2}{*}{$\begin{array}{c}\text { Standardized } \\
\text { Coefficients } \\
\text { Beta }\end{array}$} & \multirow[t]{2}{*}{$\mathrm{t}$} & \multirow[t]{2}{*}{ Sig. } \\
\hline & & $B$ & Std. Error & & & \\
\hline \multirow{3}{*}{1} & (Constant) & 1.361 & .369 & & 3.689 & .001 \\
\hline & Kompensasi & .355 & .159 & .396 & 2.239 & .032 \\
\hline & Disiplin kerja & .385 & .149 & .458 & 2.586 & .014 \\
\hline
\end{tabular}

a. Dependent Variable: Kinerja perangkat desa

Berdasarkan data SPSS di ketahui bahwa konstanta (a) adalah 1,361. dan koefisien $\mathrm{X}_{1}\left(\mathrm{~b}_{1}\right)$ adalah 0,385 dan koefisien $\mathrm{X}_{2}\left(\mathrm{~b}_{2}\right)$ adalah 0,355 dengan persamaan regresi berganda adalah $\mathrm{Y}=1,361+0,355 \mathrm{X}_{1} 0,385 \mathrm{X}_{2}$

\section{Analisis Korelasi Berganda $(\mathbf{R})$ dan Keofisien Determinasi $\left(\mathbf{R}^{2}\right)$}

Tabel 3. Uji Koefisien Korelasi

Model Summary

\begin{tabular}{|c|c|c|c|c|}
\hline Model & $\mathrm{R}$ & R Square & $\begin{array}{l}\text { Adjusted R } \\
\text { Square }\end{array}$ & $\begin{array}{l}\text { Std. Error of the } \\
\text { Estimate }\end{array}$ \\
\hline 1 & $.813^{\mathrm{a}}$ & .661 & .640 & .25218 \\
\hline
\end{tabular}

Pada tabel 3 diketahui bahwa $\left(\mathrm{X}_{1}\right)$ Kompensasi dan $\left(\mathrm{X}_{2}\right)$ Disiplin Kerja mempunyai hubungan dengan (Y) Kinerja Perangkat Desa. Hal ini dapat dilihat dari nilai koefisien korelasi berganda $\mathrm{R}$ adalah 0,813 artinya memiliki pengaruh yang sangat kuat serta searah. dan selanjutnya diuji dengan Koefisien determinasi berganda $\left(\mathrm{R}^{2}\right)$ adalah 0,661. hal ini menunjukkan bahwa $\left(\mathrm{X}_{1}\right)$ Kompensasi dan $\left(\mathrm{X}_{2}\right)$ disiplin kerja secara bersama-sama dapat memberikan sumbangan terhadap variabel (Y) Kinerja Perangkat Desa sebesar 66,1\%. Dan sisanya 33,9\% di pengaruhi oleh variabel lain yang tidak diteliti dalam penelitian ini.

\section{Uji Asumsi Klasik}

\section{a. Normalitas}

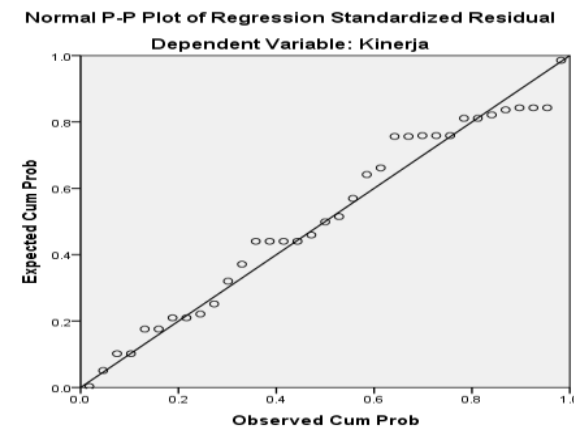

Gambar 1. Diagram Scatterplot Sub Struktural 1 
Lihat P-P Plot pada output terlihat titik-titik menyebar di sekitar garis diagonal sehingga diputuskan model regresi berdistribusi normal. Untuk estimasi normalitas dapat diketahui menggunakan Kolmogorov-Smirnov Test.

\section{b. Uji autokorelasi}

Tabel 4 : Uji Aukorelasi

Model Summary

\begin{tabular}{|l|r|r|r|r|r|}
\hline Model & \multicolumn{1}{|c|}{$\mathrm{R}$} & R Square & Adjusted R Square & $\begin{array}{c}\text { Std. Error of the } \\
\text { Estimate }\end{array}$ & Durbin-Watson \\
\hline 1 & $.813^{\mathrm{a}}$ & .661 & .640 & .25218 & 2.397 \\
\hline
\end{tabular}

a. Predictors: (Constant), kompensasi, disiplin kerja

b. Dependent Variable: Kinerja perangkat desa

Tabel 4 dapat dijelaskan Durbin-Watson. Nilai dU tabel sebesar 1,5838 sehingga batasnya antara dU dan 4-dU (1,5838 dan 2,397). Lihat output pada kotak Model Sumary terlihat nilai Durbin-Watson hitung sebesar 2,397 sehingga diputuskan bahwa tidak terdapat autokorelasi dalam model regresi.

\section{c. Uji multikolinieritas}

Tabel 5:Uji multikolinieritas

\begin{tabular}{|c|c|c|c|}
\hline \multicolumn{4}{|c|}{ Coefficients $^{a}$} \\
\hline \multirow{2}{*}{\multicolumn{2}{|c|}{ Model }} & \multicolumn{2}{|c|}{ Collinearity Statistics } \\
\hline & & Tolerance & VIF \\
\hline \multirow{3}{*}{1} & (Constant) & & \\
\hline & kompensasi & .338 & 2.958 \\
\hline & Disiplin kerja & .338 & 2.958 \\
\hline
\end{tabular}

Model

regresi bebas dari masalah multikolenieritas apabila nilai Tolerance lebih dari 0,10 dan nilai VIF kurang dari 10 yang berarti tidak ada korelasi antar variabel bebas. Lihat output pada kotak Coefficients. Semua nilai Tolerance di atas 0,10 dan nilai VIF kurang dari 10 sehingga disimpulkan bahwa model regresi bebas dari multikolenieritas.

\section{d. Uji heteroskedastisitas}

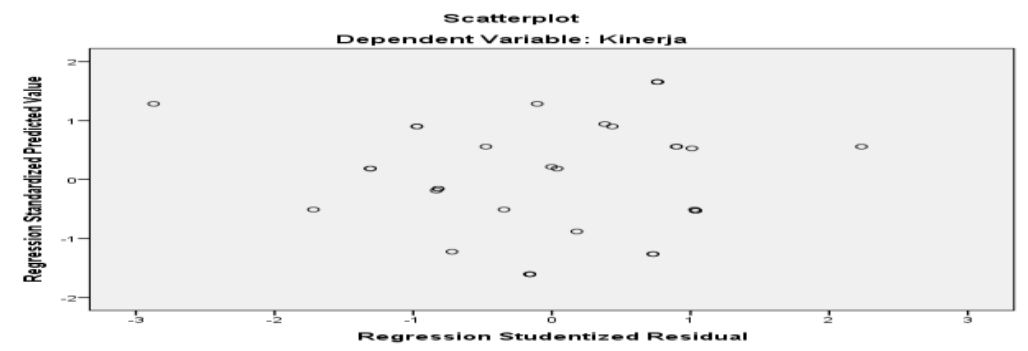

Gambar 2. Diagram Scatterplot Sub Struktural 2

Lihat Scatterplot pada output terlihat titik-titik menyebar antara -2 hingga 1 dan tidak membentuk pola tertentu sehingga disimpulkan model regresi adalah atau tidak heteroskedastisitas. 


\section{Analisis Hipotesis}

a. Uji hipotesis secara simultan (Uji Hipotesis dengan Uji "F")

Tabel 6. Uji hipotesis secara simultan

\begin{tabular}{|c|c|c|c|c|c|}
\hline \multicolumn{6}{|c|}{ ANOVA $^{a}$} \\
\hline Model & Sum of Squares & $\mathrm{df}$ & Mean Square & $\mathrm{F}$ & Sig. \\
\hline Regression & 3.972 & 2 & 1.986 & 31.234 & $.000^{6}$ \\
\hline Residual & 2.035 & 32 & .064 & & \\
\hline Total & 6.007 & 34 & & & \\
\hline
\end{tabular}

a. Dependent Variable: Kinerja aparat desa

b. Predictors: (Constant), kompensasi, disiplin kerja

Dari tabel 6 dapat dilihat F hitung yaitu 31,234 sedangkan F tabel dapat diperoleh dengan menggunakan tabel $\mathrm{F}$ dengan derajat bebas (df) residual (sisa) yaitu 32 sebagai df penyebut dan df Regresion (perlakuan) yaitu 2 sebagai df pembilang dengan taraf signifikan 0,05, sehingga diperoleh $\mathrm{F}$ tabel 3,29. karena $\mathrm{F}$ hitung $(31,234)>\mathrm{F}$ tabel $(3,29)$ maka Ho ditolak dan Ha diterima. Artinya variabel kompensasi dan disiplin kerja secara bersama - sama memiliki pengaruh signifikan terhadap kinerja perangkat desa pada Kantor Desa Sei Guntung Tengah Kecamatan Rengat Kabupaten Indragiri Hulu.

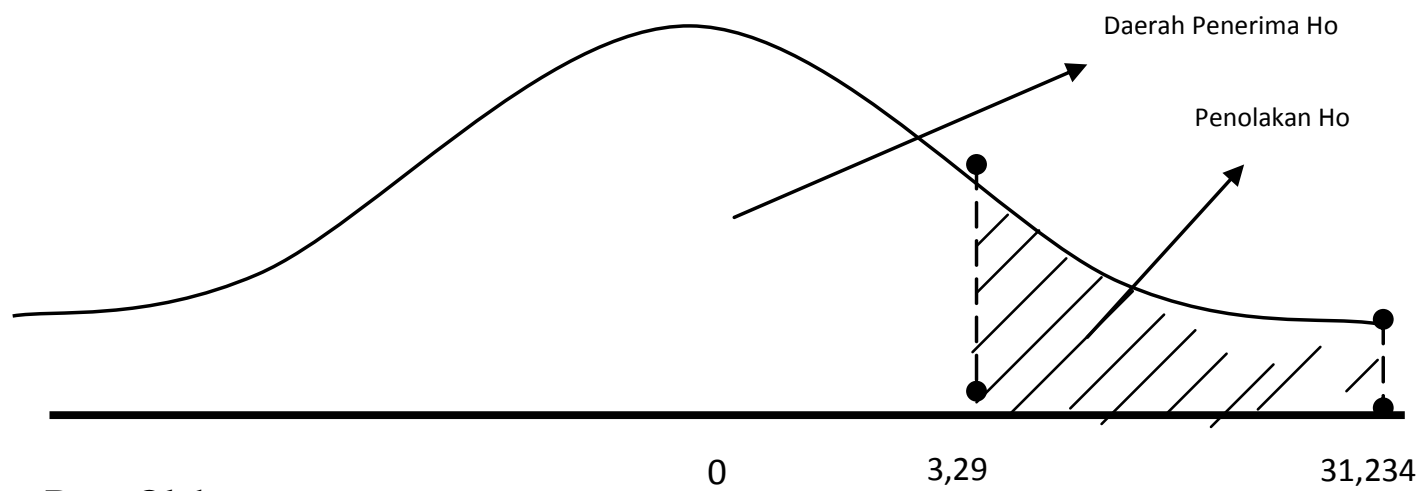

Sumber : Data Olahan

Gambar 3 : Kurva Uji F untuk Variabel Kompensasi dan Disiplin Kerja

b. Koefisien (Uji Hipotesis dengan Uji”t”)

Tabel 7 : Uji Hipotesis dengan uji t

Coefficients $^{a}$

\begin{tabular}{|c|c|c|c|c|c|}
\hline \multirow[t]{2}{*}{ Model } & \multicolumn{2}{|c|}{$\begin{array}{l}\text { Unstandardized } \\
\text { Coefficients }\end{array}$} & $\begin{array}{c}\text { Standardized } \\
\text { Coefficients }\end{array}$ & \multirow[t]{2}{*}{$\mathrm{t}$} & \multirow[t]{2}{*}{ Sig. } \\
\hline & $B$ & Std. Error & Beta & & \\
\hline (Constant) & 1.361 & .369 & & 3.689 & .001 \\
\hline Kompensasi & .355 & .159 & .396 & 2.239 & .032 \\
\hline Disiplin Kerja & .385 & 149 & .458 & 2.586 & .014 \\
\hline
\end{tabular}

a. Dependent Variable: Kinerja perangkat desa

Kompensasi : berdasarkan tabel 7 diatas dapat kita lihat t hitung untuk variabel kompensasi adalah 2,239, pada tabel t dengan db 33 dan taraf signifikan 0,05 di peroleh 2,034. karena t hitung $(2,239)>$ dari pada t tabel $(2,034)$ maka Ho ditolak dan Ha diterima, yang berarti kompensasi memiliki pengaruh yang signifikan terhadap perangkat desa. 


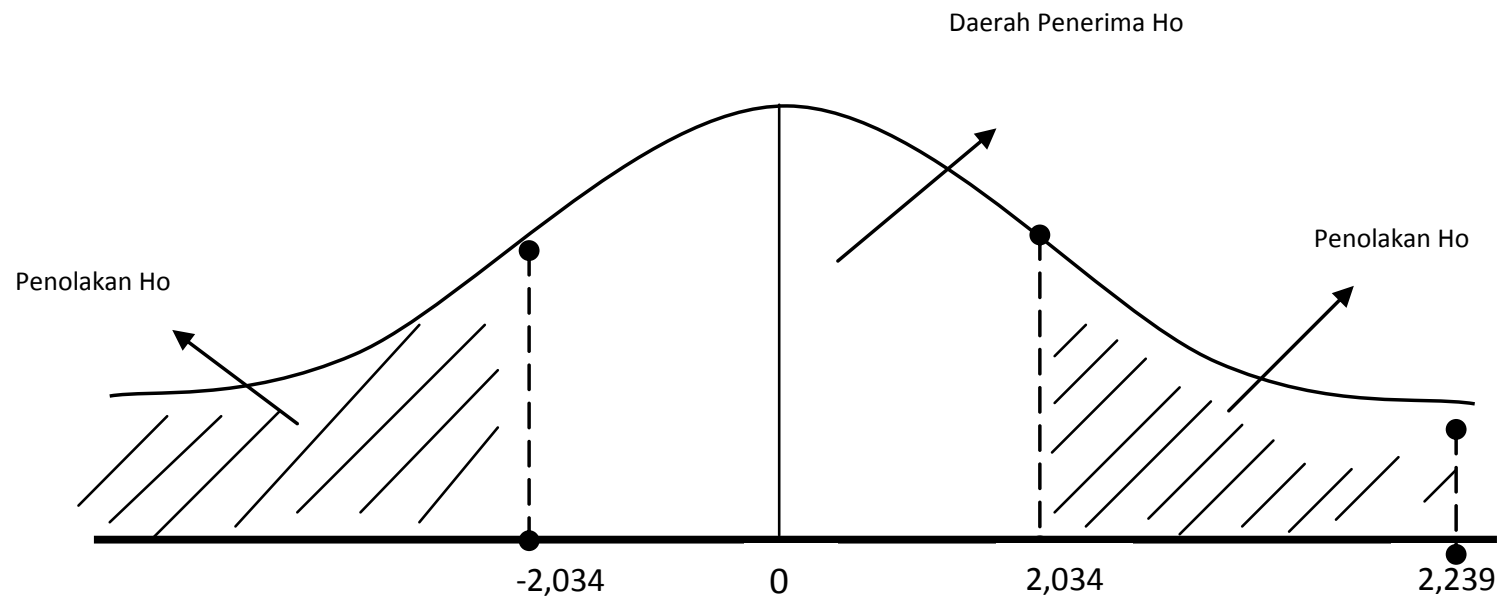

Sumber : Data Olahan

Gambar 4 : Kurva Uji t untuk Variabel Kompensasi

Disiplin kerja : berdasarkan tabel 7 diatas dapat kita lihat $t$ hitung untuk variabel Disiplin kerja adalah 2,586, pada tabel $\mathrm{t}$ dengan db 33 dan taraf signifikan $0,05 \mathrm{di}$ peroleh 2,034. karena t hitung $(2,586)>$ dari pada t tabel $(2,034)$ maka Ho ditolak dan Ha diterima, yang berarti Disiplin Kerja memiliki pengaruh yang signifikan terhadap Kinerja Perangkat Desa.

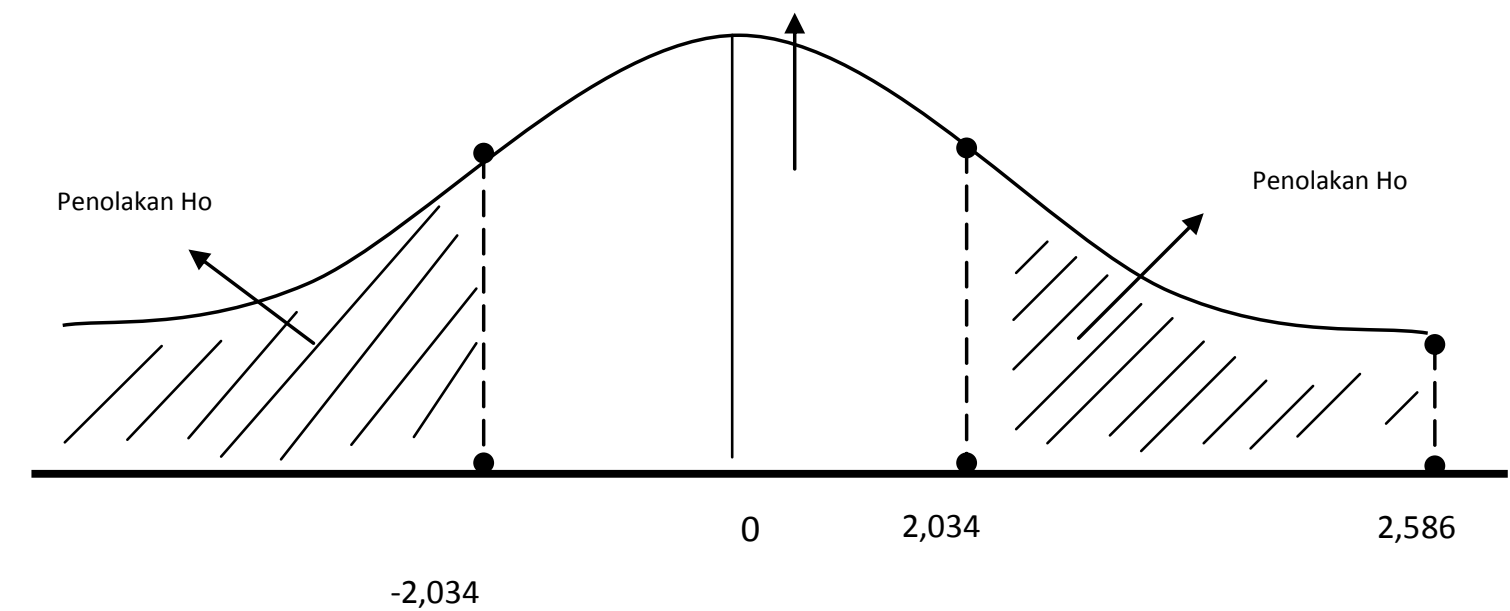

Sumber : Data Olahan

Gambar 5 : Kurva Uji t untuk Variabel Disiplin Kerja

\section{PENUTUP}

\section{A. Kesimpulan}

1. Hasi regresi berganda dengan menggunakan program SPSS adalah $\mathrm{Y}=1,361+$ $0,355 X_{1} .+0,385 X_{2}$ yang artinya $a=$ konstanta sebesar 1,361 dan jika variabel independen dianggap nol (0) maka kinerja perangkat desa dengan 1,361 artinya kinerja perangkat desa adalah sebesar 1,361 apabila $\mathrm{X}_{1}$ (kompensasi) dan $\mathrm{X}_{2}$ (disiplin kerja) sama dengan 0 (nol). $b_{1}=$ koefisien regresi kompensasi sebesar 0,355 menunjukkan bahwa setiap peningkatan kompensasi sebesar satu satuan dan variabel 
lain (disiplin kerja) tetap, maka akan terjadi peningkatan kinerja perangkat desa sebesar 0,355. $\mathrm{B}_{2}=$ koefisien regresi disiplin kerja sebesar 0,385 menunjukkan bahwa setiap peningkatan disiplin kerja sebesar satu satuan dan variabel lain (kompensasi) tetap, maka akan terjadi peningkatan kinerja perangkat desa sebesar 0,385 .

2. Nilai koefisien korelasi diketahui bahwa $\left(\mathrm{X}_{1}\right)$ Kompensasi dan $\left(\mathrm{X}_{2}\right)$ Disiplin Kerja dan mempunyai hubungan dengan (Y) Kinerja Perangkat Desa. Hal ini dapat dilihat dari nilai koefisien korelasi berganda $\mathrm{R}$ adalah 0,813 artinya memiliki hubungan yang sangat kuat serta searah. Dan selanjutnya diuji dengan Koefisien determinasi berganda $\left(\mathrm{R}^{2}\right)$ adalah 0,661 . hal ini menunjukkan bahwa $\left(\mathrm{X}_{1}\right)$ Kompensasi dan $\left(\mathrm{X}_{2}\right)$ Disiplin Kerja secara bersama-sama dapat memberikan sumbangan terhadap variabel (Y) Kinerja Perangkat Desa sebesar 66,1 \%. Dan sisanya 33,9 \% di pengaruhi oleh variabel lain yang tidak diteliti dalam penelitian ini.

3. Dari hasil perhitungan di peroleh F hitung yaitu 31,234 sedangkan F tabel dapat diperoleh dengan menggunakan tabel $\mathrm{F}$ dengan derajat bebas (df) residual (sisa) yaitu 32 sebagai df penyebut dan df Regresion (perlakuan) yaitu 2 sebagai df pembilang dengan taraf signifikan 0,05 , sehingga diperoleh $\mathrm{F}$ tabel 3,29. karena $\mathrm{F}$ hitung $(31,234)>\mathrm{F}$ tabel $(3,29)$ maka Ho ditolak dan Ha diterima. Artinya variabel Kompensasi dan Disiplin Kerja secara bersama-sama memiliki pengaruh signifikan terhadap Kinerja Perangkat Desa.

4. t hitung untuk variabel kompensasi adalah 2,239, pada tabel t dengan db 33 dan taraf signifikan 0,025 di peroleh 2,034. karena t hitung $(2,239)>$ dari pada t tabel $(2,034)$ maka Ho ditolak dan Ha diterima, yang berarti kompensasi memiliki pengaruh yang signifikan terhadap kinerja perangkat desa. t hitung untuk variabel Disiplin Kerja adalah 2,586, pada tabel t dengan db 33 dan taraf signifikan 0,025 di peroleh 2,034. karena $t$ hitung $(2,586)>$ dari pada $t$ tabel $(2,034)$ maka Ho ditolak dan Ha diterima, yang berarti Disiplin Kerja memiliki pengaruh yang signifikan terhadap Kinerja Perangkat Desa.

\section{B. Saran}

1. Hendaknya pemimpin yaitu kepala desa memberikan motivasi terhadap perangkat desa dengan memberikan contoh yaitu datang tepat waktu, memberikan penjelasan pekerjaan yang akan dilakukan.

2. Perlu adanya upaya peningkatan kinerja perangkat desa sehingga hasil kerja yang dicapai dapat memenuhi kualitas dan kuantitas sesuai dengan standar yang ditetapkan. Yaitu memberikan pelatihan bagi perangkat desa untuk menambah wawasan dan pengetahuan.

3. Perlu melakukan koordinasi, baik antara perangkat desa dengan perangkat desa maupun perangkat desa dengan kepala desa, dan selalu melibatkan perangkat desa dalam pekerjaan-pekerjaan kantor, sehingga perangkat desa merasa bagian dari organisasi tersebut. 


\section{REFERENCE}

Astarina, I. (2018). Pengaruh Motivasi Dan Kompensasi Terhadap Kinerja Karyawan Pada Pt. Alfa Scorpii Pematang Reba. Jurnal Manajemen Dan Bisnis, 7(4), 1-9. https://doi.org/10.34006/jmb.v7i4.2

Gunawan aldo Andreas, Sunardi HP, 2016. Pengaruh kompensasi dan disiplin kerja terhadap kinerja karyawan pada pt gesit nusa tangguh, jurnal ilmiah manajemen bisnis, vol. 16, no. 1.https://media.neliti.com/media/publications/98066-ID-pengaruhkompensasi-dan-disiplin-kerja-t.pdf

Handoko, T. Hani. 2011 : Manajemen, FE-UGM, Yogyakarta.

Hasibuan, Malayu S.P. 2011 : Manajemen Sumber Daya Manusia, Edisi Revisi, Cetakan Kedelapan, Bumi Aksara, Jakarta.

Iskandar, Y. (2018). Analisis Pemberian Insentif Dan Tingkat Pendidikan Terhadap Kinerja Karyawan Pada Pt. Mega Finance Cabang Rengat Kabupaten Indragiri Hulu. Jurnal Manajemen Dan Bisnis, 7(3), 76-86. https://doi.org/10.34006/jmb.v7i3.16

Kadarisman, M. 2012: Manajemen Kompensasi, Edisi 1 Cetakan 3, Rajawali pers. Jakarta.Astarina, I. (2018). Pengaruh Motivasi Dan Kompensasi Terhadap Kinerja Karyawan Pada Pt. Alfa Scorpii Pematang Reba. Jurnal Manajemen Dan Bisnis, 7(4), 1-9. https://doi.org/10.34006/jmb.v7i4.2

Putri, M. K. (2018). Pengaruh Kinerja Dosen Dan Pelayanan Administratif Terhadap Kepuasan Mahasiswa Pada Sekolah Tinggi Ilmu Ekonomi Indragiri (Stie-I) Rengat Kabupaten Indragiri Hulu. Jurnal Manajemen Dan Bisnis, 7(4), 10-21. https://doi.org/10.34006/jmb.v7i4.18

Rachmawati, Ike Kusdyah., 2008, Manajemen Sumber Daya Manusia, Penerbit Andi, Yogyakarta.

Rivai, Veithzal. 2009. Manajemen Sumber Daya Manusia untuk Perusahaan. Jakarta: Raja Grafindo Persada.

Rulyanti Dina, Andi Sularso Raden, Sayekti Tosefa, 2017. Faktor-faktor yang Mempengaruhi Kinerja Pemerintah Desa melalui Pengelolaan Keuangan Desa sebagai Variabel Intervening. Jurnal Bisnis dan Manajemen Vol. 11, No. 3 September 2017 Hal. 323 335. Bondosono Jawa Timur. file:///C:/Users/Lab/Downloads/6474-73-13177-1-1020180103.pdf

Sastrohadiwiryo, Susanto. 2006. Manajemen Tenaga Kerja Indonesia. Jakarta: Bumi Aksara.

Siswanto, Bedjo, 2005. Manajemen Tenaga Kerja, Sinar Baru, Bandung

Sugiyono, 2008 : Metode Penelitian Bisnis, Alfabeta, Bandung. 